\title{
THE EFFECT OF FINANCIAL PERFORMANCE ON SHARE RETURN WITH COMPANY SIZE AS MODERATED VARIABLES
}

(Empirical Study of Property, Real Estate, and Building Construction Companies that went public in the Kompas 100 Index 2013-2018)

\author{
Anna Christin Silaban \\ Accounting Study Program, Faculty of Economics and Business, Universitas Mercu Buana, \\ Jakarta, Indonesia
}

\begin{abstract}
The purpose of this study are as follows: 1) To examine the effect of ROA on Stock Returns; 2) To assess the effect of CR on Stock Returns; 3) To assess the effect of DER on Stock Returns; 4) To examine the effect of PER on Stock Returns; 5) To assess the effect of PBV on Stock Returns; and 6) To assess the extent to which Company Size can moderate the relationship between ROA,CR, DER, PER, PBV and Stock Return. This type of research used in this study is a casual associative research (causal associative research). The population in this study are property, real estate, and building construction companies that are included in the Kompas 100 index which are listed on the Indonesia Stock Exchange during 2013-2018. Sample selection with purposive sampling method. The analytical method used to test the hypothesis is multiple regression analysis with the absolute difference test. The results showed that: 1) ROA has a positive effect on stock returns; 2) CR does not have a significant positive effect on stock returns; 3) DER has a positive effect on stock returns; 4) PER has a positive effect on stock returns; 5) PBV has no effect on stock returns; and 6) Company size is not able to moderate the relationship between $R O A, C R, D E R, P E R, P B V$ with stock returns.
\end{abstract}

KEYWORDS: Return On Assets, Current Ratio, Debt to Equity Ratio, Price Earning Ratio, Price to Book Value, Company Size, Stock Return

\section{INTRODUCTION}

One of the things that becomes a benchmark for a country's economic development is the level of world capital market development and securities industries in that country. The capital market acts as a means to mobilize funds from parties who have excess funds to those who need funds. The presence of the capital market increases the choice of sources of funds and investment choices for investors, so that the opportunity to obtain greater returns in accordance with the characteristics of the selected investment. According Jogiyanto (2015) investment activity itself is an activity of placing funds in one or more assets during a certain period in the hope of earning income or an increase in the value of the initial investment (capital) which aims to maximize the expected return (return) within the risk limit acceptable to every investor.

The main conditions desired by investors to be willing to channel their funds through the capital market are a feeling of security of the investment being invested and the level of return that will be obtained from the investment. This feeling of security is obtained among others because investors obtain clear, reasonable and timely information as a basis for making investment decisions. Return is also the return obtained by the investor for his decision to bear the risk of the investment made, because the capital market cannot provide guarantees to investors to obtain a certain Stock Return.

Stock Return is an expected rate of return on investments made in shares or groups of shares through a portfolio. The good financial performance 


\section{EPRA International Journal of Research and Development (IJRD)}

of a company is a major consideration for investors. The better the level of financial performance of a company is expected to increase stock prices and will provide profits (return) for investors, because Stock Return is the difference between the current stock price and the previous stock price. High Stock Return is one of the attractions for investors to invest their funds in the capital market. Thus, if the company's ability to generate profits increases, the share price will also increase. Husnan (2005 in Bisara, 2015) the higher the return or profit obtained, the better the position of the company owner.

Stock Return is a factor that influences investors' interest to make an investment in a company, with the high rate of return given by the company to investors, it shows that the company has a good company performance, so investors believe that the company will have a positive effect of shares that have been invested by investors in the capital market. This situation requires sufficient funding for companies to survive and compete. One of the ways taken by companies to meet funding needs to develop in order to remain competitive is the sale of company shares to the public through the capital market. With more and more investors investing in the capital market, it will increase the value of the company, because with the number of investors who trust the company, it means the company can use its assets efficiently, so that the company's stock price will increase and the company's stock return will also increase.

Shares of companies that go public as investment commodities are classified as having a high level of risk because they are very sensitive to changes in political and economic conditions and changes that occur within the company itself. These changes can have a positive or negative impact on the company's stock price. This shows that investors need to take a cautious attitude in investing in the form of shares to prevent possible losses to be received. One of the efforts to prevent these losses is to predict the Stock Return that investors might receive in the future. Stock Return Prediction can be done by analyzing the company's performance. One of the main things that is often used to analyze company performance is by analyzing the company's finances. Corporate financial analysis requires several benchmarks. Benchmarks that are often used are financial ratios or indexes that connect two financial data with one another.

Financial ratio analysis is based on historical financial data whose main purpose is to give an indication of the company's future performance. Financial ratio analysis is an alternative to test whether financial information generated by corporate financial accounting is useful for classifying or predicting stock returns on the capital market. With financial ratio analysis, it can be seen the strengths and weaknesses of companies in the financial sector. Investors before investing in companies listed on the IDX conduct an analysis of company performance including using financial ratios to determine the company's stock returns. Investors will utilize all the information and financial performance of the company against prices in making buying or selling decisions so that the shares now reflect all known information.

According to Kasmir (2010) financial ratios are the activities of comparing numbers in financial statements by dividing one number with another number. Comparisons can be made between one component with components in one financial statement or between components that exist between financial statements. With financial ratio analysis, information can be obtained and provide an assessment of the financial condition of a company in a certain period. According to Wild and Subramanyam (2010), financial ratios consist of profitability, liquidity, solvency, activity and market ratios.

Some research on financial performance that has been linked to Stock Returns has been carried out but indicated inconsistent results. Research conducted by Bintara \& Tanjung (2019) shows that Stock Return is influenced by several factors, namely return on assets (ROA), current ratio (CR), debt to equity ratio (DER), and price earning ratio (PER). Whereas the research of Nesa (2015) shows that only ROA and DER have a significant effect on stock returns.

The inconsistency of the results of previous studies prompted researchers to add company size as a moderating variable in the relationship between financial performance and Stock Return, which later this moderating variable could strengthen or weaken the relationship between financial performance and Stock Return. Company size is the scale of the company used to reflect the size of the company based on total company assets (Puspitasari and Latrini, 2014). The size of the company is also an assessment of whether the company can use its assets well to generate profits or profits. Investors will be more confident of large-sized companies to invest their excess funds, because with large-sized companies make investors more confident to entrust their business continuity to be more secure and very unlikely bankruptcy will occur rather than investing in small companies (Mayuni and Suarjaya 2018) .

In research conducted by Surgawati, et al., (2019), Pohan, et al., (2018) and Mudjijah, et al., (2019) which states that company size is able to moderate the relationship between independent and dependent variables. This statement is different from the results of research by Yuliasari, et al (2019) and Apriliyanti, et al., (2019) which states that company 


\section{EPRA International Journal of Research and Development (IJRD)}

size cannot moderate the relationship between independent and dependent variables.

Researchers chose the property, real estate and building construction company because property, real estate and building construction companies play an important role in the field of economy and development in Indonesia. This sector is also one indicator to assess a country's economic development.

Based on the description above, the authors are interested in conducting a study entitled "Effect of Financial Performance on Stock Returns with Firm Size as Moderation Variables (Empirical Study of Property, Real Estate, and Building Construction Companies that go public in Kompas 100 Index 2013-2018)".

From the description of the research background above, it can formulate the main issues that will be discussed in this study, namely: 1) Does ROA affect the Stock Return; 2) Does CR affect the Stock Return; 3) Does DER affect the Stock Return; 4) Does PER affect the Stock Return; 5) Does PBV affect the Stock Return; and 6) Whether Company Size can moderate the relationship between ROA, CR, DER, PER, PBV and Stock Return.

\section{LITERATURE REVIEW Pecking Order Theory}

According to Brearley, Myers and Marcus (2008 in Sukarno et al, 2016) the pecking order theory states that companies like internal funding (ie profits, retained and reinvested) rather than external funding. If external funding is needed, they would rather issue debt than issue new shares. Debt issuance is still considered to have a small impact on stock prices and the scope of debt valuation is smaller because debt issuance is a sign that is not too alarming for investors. These observations triggered the peking order theory of capital structure which reads as follows: 1) Companies like funding from internal, because these funds are collected without sending reverse signals that can reduce share prices. 2) If external funds are needed, the company issues the debt first and only issues equity as a last resort. This Peking order arises because debt issuance is not too translated as a bad sign by investors when compared to equity issuance.

\section{Stakeholders Theory}

According to Clarkson (1995) in Hasian (2017), stakeholders are divided into two groups, namely primary and secondary. Primary stakeholders are groups of stakeholders who do not take part or participate in the operations of a company. Secondary stakeholders are groups of stakeholders who influence and are influenced by the company, but are not involved and are not so important for the survival of the company.

Stakeholder theory is a theory that states that a company is an entity that not only operates for its own interests, but must provide benefits to all its stakeholders, because the survival of a company is supported by stakeholders (Ghazali and Chariri, 2007 in Hasian, 2017) . Shareholders, creditors, consumers, suppliers, the government, the public, analysts, and other parties are stakeholder groups that are considered by the company to disclose or not reveal information in the company's financial statements. All stakeholders have the right to obtain information about company activities.

\section{Financial performance}

An assessment of a company's financial performance is defined as Performing Measurement, which means that the company's qualifications and efficiency or effectiveness in operating a business during the accounting period. So it can be interpreted that performance is a formal effort carried out by the company to evaluate the efficiency and effectiveness of the company's activities that have been carried out in a period of time. So it can be concluded to assess the financial performance of companies can use a certain measure or benchmark. Usually the measure used to measure a company's financial performance is a ratio or index that links two or more financial data.

According to Robert Ang (1997) in Nita and Silviana (2016), financial analysis is reflected in financial ratios consisting of five ratios, namely: a) Solvency Ratios; b) Market Ratio; c) Profitability Ratio; d) Liquidity Ratio; e) Activity Ratio.

In this study, fundamental analysis will be reflected by the financial ratios proxied by:

\section{a. Return On Asset (ROA)}

ROA is one ratio that measures the level of profitability of a company. ROA is used to determine the amount of net profit that can be obtained from the company's operations using all of his wealth. High and low ROA depends on the management of company assets by management that illustrates the efficiency of the company's operations. The higher the ROA the more efficient the company's operations and vice versa, the lower ROA can be caused by the number of company assets that are unemployed, investments in excess inventory, excess paper money, fixed assets operating below normal and others occur on the stock exchange (Teguh, 2014). ROA is obtained from the comparison of net income with the company's total assets.

Investors will like a company with a high ROA value because a company with a high ROA value can produce a greater profit level than a company with a low ROA value (Ang, 1997 in Teguh, 2014). The higher the value of ROA, the better the company's performance on the use of its assets.

Based on Bank Indonesia Circular Letter 


\section{EPRA International Journal of Research and Development (IJRD)}

No.13 / 24 / DPNP dated 25 October 2011 (Hafidz and Safira, 2018). Return On Assets can be calculated using the formula:

$$
R O A=\frac{\text { Laba Sebelum Pajak }}{\text { Rata }- \text { rata Total Aset }}
$$

\section{b. Current Ratio (CR)}

The most common ratio used to analyze the working capital position of a company is the current ratio, which is the ratio between the amount of current assets and current debt (Munawir, 2005 in Nesa 2015). A high CR provides a good indication of collateral for shortterm creditors in the sense that at any time the company has the ability to pay off its short-term financial obligations. However, a high CR also indicates that some working capital is not spinning or unemployed and will negatively affect the ability to earn profit / profitability (Nesa, 2015). The reduced ability of the company to earn profits will also cause a decrease in the returns that will be obtained by investors. The formula for calculating CR according to Gitman \& Zutter (2012) is:

$$
C R=\frac{\text { Current Assets }}{\text { Current Liabilities }}
$$

\section{c. Debt to Equity Ratio (DER)}

DER is a ratio that illustrates the ratio of debt and equity in company funding and shows the ability of the company's own capital to meet all its obligations (Sawir, 2000 in Nesa 2015). According to Susilowati \& Turyanto (2011) the greater use of debt, which is reflected by the greater debt ratio (ratio of debt to total assets), the same earning before interest and tax (EBIT) will result in greater earnings per share. If earnings per share increase, investor interest will also increase. This will have an impact on increasing share prices and causing an increase in stock returns. The formula of Debt to Equity Ratio (DER) according to Husnan (2015) is

$$
D E R=\frac{\text { Total Kewajiban }}{\text { Modal Sendiri }}
$$

\section{d. Price Earning Ratio (PER)}

PER is a ratio that compares the price of shares obtained from the capital market and earnings per share obtained by company owners presented in the financial statements (Wahyudiono, 2014). According to Sugiono (2009) the higher the PER ratio will indicate that the company's performance is also getting better. But on the contrary, if the PER is too high it can also indicate that the stock price offered is already very high or irrational. Caution is needed in analyzing PER because the analysis can be misleading. The formula used to calculate the amount of PER according to Husnan (2015) is:

$$
P E R=\frac{\text { Harga Saham }}{\text { Laba per lembar saham }}
$$

\section{e. Price to Book Value (PBV)}

According to Darmadji \& Fakhruddin (2001) PBV illustrates how much the market values the book value of a company's shares. If PBV is high, market confidence in the company's prospects going forward is also high. PBV ratio is usually used for investors in making investment decisions. The higher the PBV, the higher the share price. The higher the stock price, the higher the stock return will be. This ratio is calculated using the following formula (Robert, 1997):

$$
P B V=\frac{\text { Harga pasar per lembar saham }}{\text { Nilai Buku per lembar saham }}
$$

\section{Stock Return}

Stock return or stock return is one of the most important aspects in conducting investment analysis. Stock return is the level of profit that an investor will enjoy on an investment he does. The magnitude of stock returns can be seen from the existence of abnormal returns obtained by investors relating to the stock churning event.

Abnormal return is the difference between actual returns and expected returns. A positive abnormal return indicates that the return received is greater than the expected return, on the contrary if the return received is smaller than expected then it is called a negative abnormal return.

The abnormal return calculation in this study uses a market adjusted model, the market adjusted model. In this model assume that the best predictor for the return of a security is the market index return at that time. If the market index return at the time of announcement is $10 \%$ then the expected return of all securities at the same time is the same as the market index return of $10 \%$. If the return of a security at the same time is $25 \%$, the abnormal return for that security is $15 \%$ (Jogiyanto, 2015).

Some research on event studies also uses abnormal accumulation of returns. Accumulation of abnormal return or cumulative abnormal return (CAR) is the sum of the abnormal return of the previous day in the event period for each security (Jogiyanto, 2015). CAR $\mathrm{Nn}_{\mathrm{N}}$ is the daily accumulation of abnormal returns per share. The event period is determined by the researcher, which is 21 days, which is 10 days before and 10 days after the Internet 


\section{EPRA International Journal of Research and Development (IJRD)}

Volume: 6 | Issue: 1 | January 2021

- Peer Reviewed Journal

Financial Reporting.

\section{Company Size}

The size of the company is the size of the company, a large established company will have easy access to the capital market (Purnamasari \& Fitria, 2015). Large companies are given more attention by the public so they will be more careful in doing financial reporting, so that the impact of these companies is reporting conditions more accurately.

The size of the company will be symbolized by SIZE, and measured using the natural logarithm (ln) of the book value of total assets owned by the company.

\section{Prior Research}

Previous research that can support this research is as follows: Nesa (2015) in her research entitled "Analysis of Factors Affecting Stock Return (Case Study in Automotive and Components Sub Sector Companies Listed on Indonesia Stock Exchange Period 2010-2014)" . The results showed that only ROA and DER variables significantly influence Stock Return. While the current ratio (CR), price earning ratio (PER) and price to book value (PBV) have no effect on stock returns.
Vitri and Indra (2018) in their research entitled "Effect of Debt to Equity Ratio, Total Asset Turnover, Inflation and BI Rate on Stock Returns". The results showed that inflation and the BI rate had a significant effect on stock returns. Whereas Debt to Equity Ratio (DER) and Total Asset Turn Over (TATO) have no effect on Stock Returns.

Solihati (2019) in her research entitled "Analysis of Factors Affecting Abnormal Returns in the Private Banking Sector Registered in Indonesia Stock Exchange 2015-2017". The results of this study concluded that NPM, DR, and DER had no effect on Cumulative Absolute Return. While ROE has significant and significant effect on Cumulative Absolute Return.

Bintara \& Tanjung. (2019) in his research entitled "Analysis of Fundamental Factors on Stock Return". The results of this study prove that 1) ROA has a positive effect on Stock Returns; 2) CR has a positive effect on Stock Returns; 3) DER has a negative impact on Stock Returns; 4) PER has a positive effect on stock returns; and 5) PBV does not affect Stock Return.

\section{Thought Framework}

Based on the theoretical foundation and previous studies, the researcher develops the research framework tested as shown in the following figure:

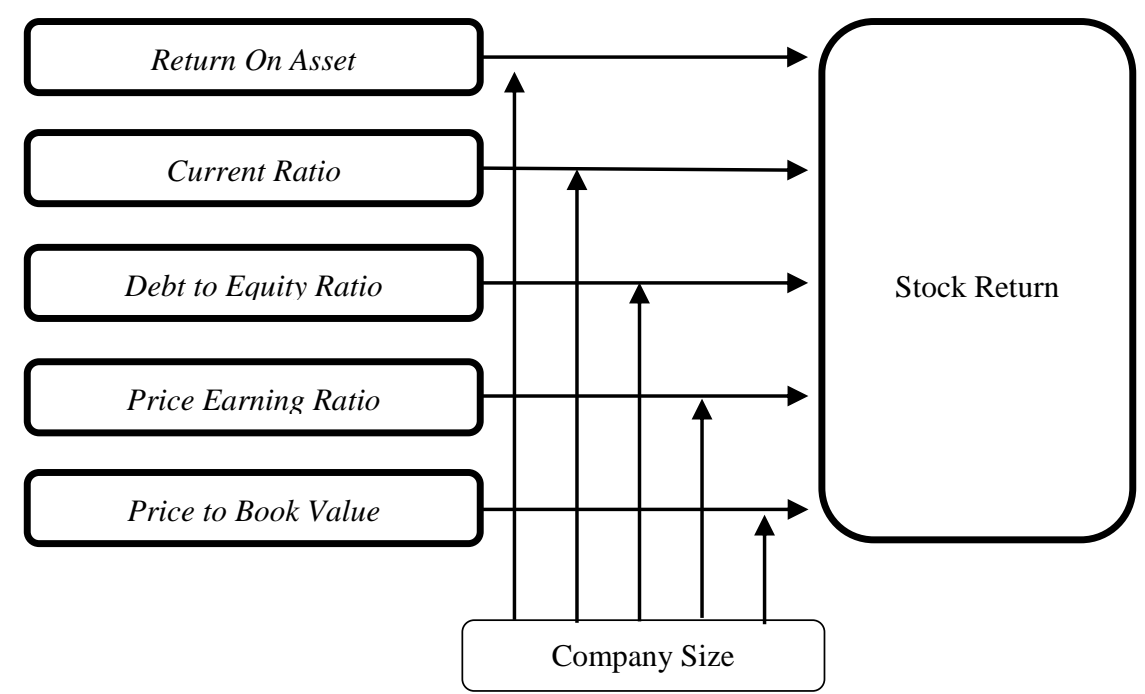

Gambar 1.1 Rerangka Pemikiran

\section{Hypothesis} follows:

Ha1 : Return On Assets affect Stock Return

Ha2 : Current Ratio affects Stock Return

Ha3 : Debt to Equity Ratio affects the Stock Return

Ha4 : Price Earning Ratio affects Stock Return
Ha5 : Price to Book Value influences Stock Return

Ha6 : Company size can moderate the relationship between Return On Assets and Stock Return

Ha7 : Company size can moderate the relationship between Current Ratio and Stock Return 
Ha8 : Company size can moderate the relationship between Debt to Equity Ratio and Stock Return

Ha9 : Company size can moderate the relationship between Price Earning Ratio and Stock Return

Ha10 : Company size can moderate the relationship between Price to Book Value and Stock Return

\section{RESEARCH METHOD \\ Types of Research}

The research used in this study is casual associative research (causal associative research). According to Sanusi (2011), associative-causal research is a research that seeks a relationship between two or more variables. The purpose of associative research is to look for relationships between one variable and another.

\section{Definition of Variable Operations}

Operational research variables on the Effect of Profitability, Capital Structure and Sales Growth on Stock Return can be summarized in table 1.1.

Table 1.1 Operasionalisasi Variabel

\begin{tabular}{|c|c|c|c|}
\hline $\begin{array}{c}\text { Jenis } \\
\text { Variabel }\end{array}$ & Defenisi Operasional & Pengukuran & Skala \\
\hline \multicolumn{4}{|l|}{ Dependent } \\
\hline Stock Return & $\begin{array}{l}\text { Profit enjoyed by investors for their stock } \\
\text { investments (Jogiyanto, 2015) }\end{array}$ & $\sum_{t=-10}^{t=+10}$ AARnt & Rasio \\
\hline \multicolumn{4}{|l|}{$\begin{array}{l}\text { Independe } \\
\text { nt }\end{array}$} \\
\hline $\begin{array}{ll}\text { Return } & \text { On } \\
\text { Assets } & \end{array}$ & $\begin{array}{l}\text { Ratios used to measure the effectiveness of } \\
\text { management in generating profits with available } \\
\text { assets (Gitman \& Zutter, 2012) }\end{array}$ & $\frac{\text { Laba Sebelum Pajak }}{\text { Rata-rata Total Aset }}$ & Rasio \\
\hline $\begin{array}{l}\text { Current } \\
\text { Ratio }\end{array}$ & $\begin{array}{l}\text { A ratio that measures the extent to which a } \\
\text { company's current assets are used to meet its } \\
\text { current liabilities. }\end{array}$ & $\frac{\text { Current Assets }}{\text { Current Liabilities }}$ & Rasio \\
\hline $\begin{array}{l}\text { Debt to } \\
\text { equity ratio }\end{array}$ & $\begin{array}{l}\text { Comparison between all corporate debt both } \\
\text { long-term debt and short-term debt with the } \\
\text { company's own capital }\end{array}$ & $\frac{\text { Total Kewajiban }}{\text { Modal Sendiri }}$ & Rasio \\
\hline $\begin{array}{l}\text { Price } \\
\text { Earning } \\
\text { Ratio }\end{array}$ & $\begin{array}{l}\text { The ratio of the ratio between the share price to } \\
\text { the income of each share, and is an indicator of } \\
\text { the company's development or growth in the } \\
\text { future (prospects of the firm). }\end{array}$ & $\frac{\text { Harga Saham }}{\text { Laba per lembar saham }}$ & Rasio \\
\hline $\begin{array}{l}\text { Price to } \\
\text { Book Value }\end{array}$ & $\begin{array}{l}\text { Market ratio (market ratio) which is used to } \\
\text { measure the performance of the stock market } \\
\text { price to the book value. }\end{array}$ & $\frac{\text { Harga pasar per lembar sa }}{\text { Nilai Buku per lembar sah }}$ & Rasio \\
\hline \multicolumn{4}{|l|}{ Moderating } \\
\hline $\begin{array}{l}\text { Company } \\
\text { Size }\end{array}$ & $\begin{array}{l}\text { Large-scale small companies, an established } \\
\text { large company will have easy access to the } \\
\text { capital market (Purnamasari \& Fitria, 2015) }\end{array}$ & $\begin{array}{c}\text { Logaritma Natural Total } \\
\text { Aset }\end{array}$ & Rasio \\
\hline
\end{tabular}

\section{Data Types and Sources}

The data used in conducting this research is secondary data, that is data obtained through intermediaries from both parties and certain media that support this research. The data used in this study are secondary data in the form of financial statements of property companies, real estate, and building construction which were listed on the IDX during 2013-2018 obtained from the Indonesia Stock Exchange website (www.idx.co.id) and the site official of each of these companies.

\section{Research Population}

The population in this study are property, real estate, and building construction companies listed on the Indonesia Stock Exchange (IDX) in the period 2013-2018.

\section{Research Samples}

The sample is part of the population used to estimate population characteristics. The sampling technique is using purposive sampling technique. According to Widyani (2010) the purposive sampling method is the selection of samples on the basis of the suitability of the characteristics of the sample with the 
specified sample selection criteria. The sample criteria used in this study are:

1) Property, Real Estate and Building Construction Companies listed on the Indonesia Stock Exchange (IDX) for the period 2013-2018.

2) Publish audited financial statements for the period 2013-2018

3) The company did not experience a loss during the study year.

4) Data owned by the company are complete and in accordance with the variables studied.

According to the criteria above, the number of samples used were 13 companies during the 6 periods namely 2013, 2014, 2015, 2016, and 2018. Then obtained a total sample of 13 companies $\times 6$ periods $=$ 78 data to be used in this study.

\section{Data Collection Technique}

Data collection methods in this research are literature study and documentation methods. Literature study method by studying literature and reviewing a variety of literature literature such as various journals, articles and other literature books that support the research process. While the documentation method is the process of collecting data by recording documents related to this research.

\section{Analysis Method Descriptive Statistics}

Descriptive statistics in this study are used to provide a description of the character of the research variable using a frequency distribution table that shows the mode number, the range of scores and the standard division

\section{Classic Assumption Test}

This research was conducted with a simple regression analysis. The use of simple regression analysis must be free from testing classic assumptions. For this reason, before a simple regression analysis is required, classical assumptions must be tested first. Testing classic assumptions is done using normality test, multicollinearity test, heterokedasticity test and autocorrelation test.

\section{Hypothesis Testing}

In this study, researchers used five independent variables, one dependent variable and one moderating variable. There are three ways to test regression with moderating variables, namely the interaction test, the absolute difference test, and the residual test. In this study, researchers used the absolute value test. Because according to Furcot and Shearon (Ghozali, 2013) the absolute difference value test is more accurate. The step of the absolute difference test in this study can be described by the regression equation as follows: $Y=\alpha+\beta_{1} X_{1}+\beta_{2} X_{2}+\beta_{3} X_{3}+\beta_{4} X_{4}+$ $\beta_{5} X_{5}+\beta_{6} X_{6}+\beta_{7} \operatorname{Abs}\left(Z X_{1}-Z X_{6}\right)+\beta_{8} \operatorname{Abs}\left(Z X_{2}-Z_{6}\right)+$ $\beta_{9} \operatorname{Abs}\left(Z X_{3}-Z X_{6}\right)+\beta_{10} \operatorname{Abs}\left(Z X_{4}-Z X_{6}\right)+\beta_{11} \operatorname{Abs}\left(Z X_{5^{-}}\right.$ $\left.\mathrm{ZX}_{6}\right)+\varepsilon$

Where :

$\mathrm{Y}=$ Stock Return

$\alpha=$ konstanta

$\beta=$ number or direction of the regression coefficient, which shows the number of increase or decrease in the dependent variable based on the independent variable

$\mathrm{X}_{1}=$ Return on Asset

$\mathrm{X}_{2}=$ Currents Ratio

$\mathrm{X}_{3}=$ Debt to Equity Ratio

$\mathrm{X}_{4}=$ Price Earning Ratio

$\mathrm{X}_{5}=$ Price to Book Value

$\mathrm{X}_{6}=$ Company Size

Abs $=$ is an interaction that is measured by absolute value

$\varepsilon=$ error

In this study the significance level ( $\alpha$ ) of 0.05 or $5 \%$ was used. This multiple regression analysis was carried out with the help of the SPSS (Statistical Package For Social Sciences) Release 25.0 for Windows program so that the coefficient of determination, the statistical $F$ value and the statistical $\mathrm{t}$ value used in hypothesis testing can be obtained. 


\section{EPRA International Journal of Research and Development (IJRD)}

Volume: 6 | Issue: 1 | January 2021

- Peer Reviewed Journal

\section{RESEARCH RESULTS AND DISCUSSION \\ Research Data Description}

The following are descriptive statistical results about the research variables as follows:

Table 1.2 Descriptive Statistics Results

\begin{tabular}{|l|c|c|c|c|c|}
\hline \multicolumn{1}{|c|}{ Variabel } & N & Min & Max & Mean & $\begin{array}{c}\text { Std. } \\
\text { Deviation }\end{array}$ \\
\hline Return On Assets & 78 & 0,01 & 0,24 & 0,07 & 0,042 \\
\hline Current Ratio & 78 & 0,65 & 17,72 & 2,19 & 2,157 \\
\hline Debt to Equity Ratio & 78 & 0,28 & 5,37 & 1,63 & 1,212 \\
\hline Price Earning Ratio & 78 & 1,95 & 80,17 & 14,89 & 10,557 \\
\hline Price to Book Value & 78 & 0,23 & 7,41 & 1,67 & 1,203 \\
\hline Company Size & 78 & 28,87 & 32,45 & 30,58 & 0,749 \\
\hline Stock Return & 78 & $-0,01$ & 0,02 & 0,0004 & 0,0054 \\
\hline
\end{tabular}

Based on table 1.2 above, it can be presented descriptive statistical results about the research variables as follows: The average value of Return on Assets (ROA) is 0.07 or $7 \%$, with a standard deviation of 0.042 or $4.2 \%$, which means the data The amount used is highly fluctuating from 2013 to 2018 . The variable ROA ranges from the lowest value of 0.01 (1\%), namely the Sentul City Tbk company in 2015 to the highest value of 0.24 (24\%), the Bekasi Fajar Industrial Estate company in 2013. The average value of ROA of 0.07 shows that for every Rp 1 of the funds invested by investors as share capital, will generate a net profit of $7 \%$.

Current Ratio variable has an average of $2.19 \%$ with a standard deviation value of $2.157 \%$, this shows that the data used fluctuate greatly from 2013 to 2018. Current Ratio variables range from the lowest value of $0.65 \% \%$ ie the company Alam Sutera Realty Tbk. 2018 up to the highest value of $17.72 \%$, namely the Bekasi Fajar Industrial Estate company in 2018.

Debt to Equity Ratio variable has an average ratio of $1.63 \%$ with a standard deviation value of $1.212 \%$, this shows that the data used is highly fluctuating from 2013 to 2018. Debt to Equity Ratio variable ranges from the lowest value of $0,28 \%$, namely Bekasi Fajar Industrial Estate company in 2014 up to the highest value of $5.37 \%$, namely the company Adhi Karya (Persero) Tbk. Year 2014.

Price Earning Ratio variable has an average of $14.89 \%$ with a standard deviation value of $10.557 \%$, this shows that the data used is highly fluctuating from 2013 to 2018. Price Earning Ratio variable ranges from the lowest value of $1.95 \%$ ie the company Surya Semesta Internusa Tbk in 2017 up to the highest value of $80.17 \%$, namely the company Sentul City Tbk in 2014.

Price to Book Value variable has an average of $1.67 \%$ with a standard deviation value of $1.203 \%$, this shows that the data used fluctuated greatly from 2013 to 2018. Price to Book Value variables ranged from the lowest value of $0.23 \%$ namely Lippo Karawaci Tbk company. in 2018 up to the highest value of $7.41 \%$, namely the company PP (Persero) Tbk in 2014.

The average value of company size measured by natural logarithm of total assets is 30.58 trillion with a standard deviation value of 0.749 trillion, which means the data used is highly fluctuating from 2013 to 2018. Company size ranges from the lowest value of 28.84 trillion, namely the Bekasi Fajar Industrial Estate company in 2013 up to the highest value of 32.45 trillion, namely the Waskita Karya (Persero) Tbk company in 2018. The average value of the company size of 30.58 shows that the average sample company has asset stability amounting to 30.58 trillion.

The average value of the Stock Return Variable measured by Cumulative Abnormal Return (CAR) of 0,0004 with a standard deviation value of 0.0054 , which means the data used is highly fluctuating from 2013 to 2018. Cumulative Abnormal Return ranges from the lowest value of -0.01 , namely the Sentul City Tbk company in 2016 up to the highest value of 0.02 , namely the Adhi Karya (Persero) Tbk company. in 2016. The average value of Cumulative Abnormal Return of 0,0004 shows that as many as $0.04 \%$ of companies received a positive market response from investors.

\section{Classic Assumption Test Normality test}

Thus the overall results of the normality test percountan using the Lilliefors test can be seen in the summary in table 1.3. 
EPRA International Journal of Research and Development (IJRD)

Volume: 6 | Issue: 1 | January 2021

Table 1.3 Summary of the Normality Test

\begin{tabular}{|c|c|c|c|c|c|c|}
\hline \multirow{2}{*}{ No } & \multirow{2}{*}{ Taksiran } & \multirow{2}{*}{$\mathrm{n}$} & $\mathrm{L}$ Count & \multicolumn{2}{|c|}{$\mathrm{L}_{\text {Table }}$} & \multirow{2}{*}{ Keputusan } \\
\cline { 5 - 6 } & & & $\alpha=0,05$ & $\alpha=0.01$ & \\
\hline 1 & Y atas X1 & 78 & $-0,1064$ & 0,1003 & 0,1167 & Normal \\
\hline 2 & Y atas X2 & 78 & $-0,1061$ & 0,1003 & 0,1167 & Normal \\
\hline 3 & Y atas X3 & 78 & $-0,1126$ & 0,1003 & 0,1167 & Normal \\
\hline 4 & Y atas X4 & 78 & $-0,1061$ & 0,1003 & 0,1167 & Normal \\
\hline 5 & Y atas X5 & 78 & $-0,0970$ & 0,1003 & 0,1167 & Normal \\
\hline 6 & Y atas X6 & 78 & $-0,1061$ & 0,1003 & 0,1167 & Normal \\
\hline
\end{tabular}

Source: Primary data processed (2020)

\section{Multicollinearity Test}

The results of the autocorrelation test can be seen in Table 1.4. following.

Table 1.4 Summary of Multicollinearity Tests

\begin{tabular}{|l|c|c|}
\hline \multirow{2}{*}{\multicolumn{1}{|c|}{ Variabel }} & \multicolumn{2}{c|}{ Collinearity Statistics } \\
\cline { 2 - 3 } & Tolerance & VIF \\
\hline Return On Assets & 0,445 & 2,246 \\
\hline Current Ratio & 0,909 & 1,101 \\
\hline Debt to Equity Ratio & 0,525 & 1,904 \\
\hline Price Earning Ratio & 0,548 & 1,825 \\
\hline Price to Book Value & 0,444 & 2,252 \\
\hline Company Size & 0,791 & 1,264 \\
\hline
\end{tabular}

Source: Primary data processed (2020)

\section{Autocorrelation Test}

The autocorrelation test results can be seen in Table 1.5 below:

Table 1.5 Autocorrelation test results

\begin{tabular}{|c|c|c|c|c|c|}
\hline Model & R & R Square & $\begin{array}{c}\text { Adjusted R } \\
\text { Square }\end{array}$ & $\begin{array}{c}\text { Std. Error of } \\
\text { the Estimate }\end{array}$ & Durbin-Watson \\
\hline 1 & $0,714^{\mathrm{a}}$ & 0,510 & 0,469 & 0,00395939 & 1,825 \\
\hline
\end{tabular}

Based on SPSS output, the Durbin Watson statistical value is 1,825 . While from the Durbin Watson table with $\mathrm{n}=78$ and $\mathrm{k}=6$, the $\mathrm{d}$ table is obtained ie dl (outer boundary) $=1.471$ and du (inner limit $)=1.801$ with a significance level of $5 \%, 4-\mathrm{du}=$ 2.199; and 4-dl = 2,529; then from accounting it is concluded that the DW-test is located in the test area. Referring to Ghozali (2010), the regression model in this study is free from the autocorrelation problem because the Durbin Watson values are between du and $4 \mathrm{du}$.

\section{Heteroscedasticity Test}

The test results using the Spearman rank test can be seen in the following table 1.6:

Table 1.6 Heteroscedasticity Test Results

\begin{tabular}{|c|c|c|c|c|c|c|c|}
\hline & & $\mathrm{X} 1$ & $\mathrm{X} 2$ & X3 & $\mathrm{X} 4$ & $\mathrm{X} 5$ & X6 \\
\hline \multirow{3}{*}{ 疍 } & $\begin{array}{l}\text { Correlation } \\
\text { Coefficient }\end{array}$ &,$- 058^{* *}$ & 055 & 112 & ,054 &,$- 166^{*}$ & 117 \\
\hline & Sig. (2-tailed) & 0,061 & 0,632 & 0,329 & 0,637 & 0,089 & 0,306 \\
\hline & $\mathrm{N}$ & 78 & 78 & 78 & 78 & 78 & 78 \\
\hline
\end{tabular}

Source: Primary data processed (2020)

Spearman rank test results in the table above shows the significance value of each variable of $0.061 ; 0.632 ; 0.329 ; 0.637 ; 0.089$ and 0.306. Because the significance value of each variable is greater than 0.05 , it can be concluded that the data are free from heterocedasticity.

\section{Test the value of absolute difference}

Analysis by testing the absolute difference value is carried out with the help of the SPSS (Statistical Package for Social Sciences) Release 25.0 for Windows program. From the data processing through 
the SPSS program the following results were obtained:

Table 1.7 Results of moderating variable regression analysis

\begin{tabular}{|c|c|c|c|c|c|c|c|}
\hline Keterangan & B & $t_{\text {table }}$ & $t_{\text {count }}$ & Sig & Adj $R^{2}$ & $F_{\text {count }}$ & Sig \\
\hline (Constant) & $\begin{array}{c}- \\
0,020\end{array}$ & & & & \multirow{12}{*}{0,480} & \multirow{12}{*}{7,463} & \multirow{12}{*}{0.000} \\
\hline $\mathrm{X} 1$ & 0,075 & 1.665 & 2,417 & 0,018 & & & \\
\hline $\mathrm{X} 2$ & 0,001 & 1.665 & 1,820 & 0,073 & & & \\
\hline $\mathrm{X3}$ & 0,004 & 1.665 & 6,284 & 0,000 & & & \\
\hline $\mathrm{X} 4$ & 0,000 & 1.665 & 2,431 & 0,018 & & & \\
\hline $\mathrm{X5}$ & $\begin{array}{c}- \\
0,003\end{array}$ & 1.665 & $\begin{array}{c}- \\
1,734\end{array}$ & 0,088 & & & \\
\hline $\mathrm{X6}$ & 0,000 & 1.665 & 0,385 & 0,702 & & & \\
\hline AbsZX1-ZX6 & $\begin{array}{c}- \\
0,001 \\
\end{array}$ & 1.665 & $\begin{array}{c}- \\
0,547 \\
\end{array}$ & 0,586 & & & \\
\hline AbsZX2-ZX6 & $\begin{array}{c}- \\
0,001\end{array}$ & 1.665 & $\begin{array}{c}- \\
1,362\end{array}$ & 0,178 & & & \\
\hline AbsZX3-ZX6 & 0,000 & 1.665 & $\begin{array}{c}- \\
0,392 \\
\end{array}$ & 0,697 & & & \\
\hline AbsZX4-ZX6 & $\begin{array}{c}- \\
0,001 \\
\end{array}$ & 1.665 & 0,930 & 0,356 & & & \\
\hline AbsZX5-ZX6 & 0,001 & 1.665 & 0,621 & 0,537 & & & \\
\hline
\end{tabular}

Source: Primary data processed (2020)

Based on the regression results above, an equation can be formed as follows: $\mathrm{Y}=-0,020$ $+0,075 \mathrm{X} 1+0,001 \mathrm{X} 2+0,004 \mathrm{X} 3+0,000 \mathrm{X} 4-$ $0,003 X 5+0,000 X 6-0,001$ Abs (ZX1-ZX6) $0,001 \mathrm{Abs}(\mathrm{ZX2}-\mathrm{ZX} 6)+0,000 \mathrm{Abs}(\mathrm{ZX} 3-\mathrm{ZX} 6)-$ 0,001 Abs $(Z X 4-Z X 6)+0,001$ Abs $(Z X 5-Z X 6)+\varepsilon$

From table 1.7 it is known that the adjusted $\mathrm{R}$ square value is 0.480 . This means that $48 \%$ of Stock Return can be influenced by Return On Assets, Current Ratio, Debt to Equity Ratio, Price Earning Ratio, Price to Book Value, Company Size, AbsZX1ZX6, AbsZX2-ZX6, AbsZX3-ZX6, AbsZX4-ZX6 and AbsZX5-ZX6, the remaining 52\% (100\% - 48\%) is explained by other causes outside the model.

From the Anova test or the F test in table 1.7 above, the calculated $\mathrm{F}$ value is 7.463 with a significance probability that indicates 0,000 . Test probability values are much smaller than $\alpha=0.05$. This shows that together (simultaneously) Stock Return can be influenced by Return On Assets, Current Ratio, Debt to Equity Ratio, Price Earning Ratio, Price to Book Value, Company Size, AbsZX1ZX6, AbsZX2-ZX6, AbsZX3-ZX6, AbsZX4-ZX6 and AbsZX5-ZX6.

\section{Hypothesis test \\ Effect of Return on Assets on Stock Return}

Based on the calculation results in table 1.7 above shows that the Return on Assets variable has a positive effect on Stock Return, which can be seen from the comparison between ttable and tcount, ie ttable is smaller than ttest, with a ttable value of 1.665 and ttt 2.417 and a significance level smaller than 0.05. Thus Ha1 received.

\section{Effect of Current Ratio on Stock Return}

Based on the calculation results in table 1.7 above shows that the Current Ratio variable does not have a significant positive effect on Stock Return, which can be seen from the comparison between ttable and tcount, which is smaller than ttest, with a ttable value of 1.665 and ttest 1.820 and a greater significance level from 0.05 . Thus $\mathrm{Ha} 2$ rejected.

\section{Effect of Debt to Equity Ratio on Stock Return}

Based on the calculation results in table 4.6 above shows that the Debt to Equity Ratio variable has a positive effect on Stock Return, which can be seen from the comparison between ttable and tcount, which is ttable smaller than tcount, with a table value of 1.665 and tcount 6.284 and a significance level that is located below 0.05 . Thus $\mathrm{Ha} 3$ received.

\section{Effect of Price Earning Ratio on Stock Return}

Based on the calculation results in table 1.7 above shows that the Price Earning Ratio variable has a positive effect on Stock Return, which can be seen from the comparison between ttable and tcount, ie ttable is smaller than tcount, with a ttable value of 1.665 and ttest 2.431 and a level of significance that is at below 0.05. Thus Ha4 received. 


\section{EPRA International Journal of Research and Development (IJRD)}

\section{Effect of Price to Book Value on Stock Returns}

Based on the calculation results in table 1.7 above shows that the Price to Book Value variable has a significant negative effect on Stock Return, which can be seen from the comparison between ttable and tcount, which is ttable smaller than tcount, with a ttable value of 1.665 and tcount -1.734 and the level significance is above 0.05 . Thus $\mathrm{Ha} 5$ was rejected.

\section{Company size can moderate the relationship between Return On Assets and Stock Return}

Based on the calculation results in table 1.7 above it can be seen that the tcount AbsZX1-ZX6 (moderator) $=-0.547$ with a significance of 0.586 . This means that company size cannot strengthen / weaken the relationship between Return On Assets and Stock Return because the direction is negative and the value of AbsZX1-ZX6 (moderator) is smaller than ttable. Thus Ha6 was rejected.

\section{Company size can moderate the relationship between Current Ratio and Stock Return}

Based on the calculation results in table 1.7 above it can be seen that the tcount AbsZX2-ZX6 (moderator) $=-1.382$ with a significance of 0.178 . This means that company size cannot strengthen / weaken the relationship between Current Ratio and Stock Return because the direction is negative and the value of AbsZX2-ZX6 (moderator) is smaller than ttable. Thus Ha7 was rejected.

\section{Company size can moderate the relationship between Debt to Equity Ratio with Stock Return}

Based on the calculation results in table 1.7 above it can be seen that the tcount AbsZX3-ZX6 (moderator) $=-0.392$ with a significance of 0.697 . This means that company size cannot strengthen / weaken the relationship between Debt to Equity Ratio with Stock Return because the direction is negative and the value of AbsZX3-ZX6 (moderator) is smaller than ttable. Thus Ha8 was rejected.

\section{Company size can moderate the relationship between Price Earning Ratio and Stock Return}

Based on the calculation results in table 1.7 above it can be seen that the tcount AbsZX4-ZX6 (moderator) $=-0.930$ with a significance of 0.356 . This means that company size cannot strengthen / weaken the relationship between Price Earning Ratio and Stock Return because the direction is negative and the value of AbsZX4-ZX6 (moderator) is smaller than ttable. Thus $\mathrm{Ha} 9$ was rejected.

\section{Company size can moderate the relationship between Price to Book Value and Stock Return}

Based on the calculation results in table 1.7 above it can be seen that the tcount AbsZX5-ZX6 (moderator) $=0.621$ with a significance of 0.537 . This means that company size cannot strengthen / weaken the relationship between Price to Book Value and Stock Return because the direction is negative and the value of AbsZX5-ZX6 (moderator) is smaller than ttable. Thus Ha10 was rejected.

\section{DISCUSSION \\ Effect of Return on Assets on Stock Returns}

From the results of the study note that Return On Assets has a positive effect on Stock Return. This shows that the better the company's financial performance, the higher the stock returns. The results of this evidence show that companies with good or increasing returns on assets have the potential to attract investors to the company. This condition makes the company's stock price increase so that the increase in return on assets will have an impact on the company's stock return.

Return On Assets (ROA) is used to measure the effectiveness of a company in generating profits by utilizing its assets. Increased ROA means that the company's performance is getting better and will be responded by the market and investors by buying shares, as a result the company's stock price is increasing. With the increase in stock prices, the company's stock returns are also increasing, the theory is supported by signal theory which is a guide for investors to assess the company's prospects.

These results support research conducted by Farkhan \& Ika (2012), Bramantyo and Daljono (2013), Bintara (2015), Nesa (2015), and Heryanto (2016) which states that the Return on Assets variable has a positive effect on the company's stock returns. However, the results of this study are not in line with research conducted by Yeye (2011), Arista \& Astohar (2012), Widyawati (2012), and Thrisye \& Simu (2013) which states that ROA has no effect on stock returns.

\section{Effect of Current Ratio on Stock Return}

From the results of the study note that the Current Ratio has not a significant positive effect on Stock Return. The results of this study indicate that if the better the current ratio reflects the more liquid the company is, so that the ability to meet its short-term capabilities is higher, this will be able to increase the 


\section{EPRA International Journal of Research and Development (IJRD)}

company's credibility in the eyes of investors so that it will be able to increase the company's stock return.

Current ratio shows the amount of current liabilities covered by assets that are expected to be converted into cash in the short term. The higher the current ratio, it can be said that the company has greater ability to meet its short-term financial obligations. This is supported by the balance theory which states that companies with low business risk use more debt, and use less debt at high risk.

The results of this study do not support the findings of Shandy (2013), Pinkan (2013), Awan (2014), Ayu and Gede (2016) which state that Current Ratio has an effect on Stock Return.

\section{Effect of Debt to Equity Ratio on Stock Return}

From the results of the study note that Debt to Equity Ratio has a positive effect on Stock Return. This indicates that if the company's burden is getting higher, the company's performance is getting better and this has an impact on raising stock prices in the capital market. With the increase in the company's stock price in the capital market, the return also increases.

Debt to equity ratio (DER) can provide an overview of the capital structure owned by the company so that it can be seen the level of risk of unpaid debt. The greater the debt to equity ratio, indicating the greater the company's burden on outsiders, both in the form of principal and interest on the loan. The statement is supported by a trade off theory in which a capital structure states that companies exchange tax benefits from debt financing with problems arising from potential bankruptcy.

The results of this study support the findings of Susilowati and Tri (2011), Acheaphong et. al (2014), Basalama et. Al (2017), and Bintara \& Tanjung (2019), which shows that Debt to Equity Ratio has a positive effect on stock returns. However, the results of this study are not in line with research conducted by Arista \& Astohar (2012) Gilang (2012), Thrisye \& Simu (2013), Barakat (2014) and Ayu \& Gede (2016), which state that DER has a negative and significant influence on stock returns.

\section{Effect of Price Earning Ratio on Stock Return}

From the results of the study note that the Price Earning Ratio variable has a positive effect on Stock Returns. This indicates that if the stock price gets higher, the difference between the share price of the current period and the previous period will be greater, so that capital gains will also increase, so a high PER will cause stock returns to rise.
Price Earning Ratio (PER) is used by investors to predict the company's ability to generate profits in the future. The higher the PER, the higher the share price is valued by investors on the earnings per share, so the higher PER also indicates the more expensive the shares are towards their earnings. This assumption is supported by signal theory where companies with very bright prospects do not finance through new shares, while companies with poor prospects do like funding with outside equity which causes stock prices to rise.

The results of this study support the findings of Farkhan \& Ika (2012), Malintan (2012), Aras (2014), and Ayu \& Gede (2016) which states that PER has a positive and significant effect on stock returns.

\section{Effect of Price to Book Value on Stock Returns}

From the results of the study note that Price to Book Value has no effect on Stock Return. These results support research conducted by Mathilda (2012), and Nesa 2015) this is because investors no longer think that PBV can be used as a benchmark for buying shares but rather consider other things. But these results are not in line with research conducted by Hardiningsih (2002), Margaretha \& Damayanti (2008), and Arista \& Astohar (2012) which state that PBV has a positive and significant effect on stock returns.

\section{Company size can moderate the relationship between return on assets and stock returns \\ The results showed that company size was not} able to moderate the relationship between return on assets and stock returns. This means that the size of the company does not significantly cause the relationship between return on assets and stock returns to be stronger or weaker as previously thought. The return on asset ratio shows the company's ability to manage its assets to generate profits. A larger company is more flexible in managing its resources so that it can improve the company's financial performance. Large companies tend to be more recognized by the public and will increase trust in the products produced by the company.

The results of this study support the findings of Prasetyaningrum (2014), which states that company size is not able to moderate the relationship between profitability and stock returns.

\section{Company size can moderate the relationship between Current Ratio and Stock Return}

The results showed that company size was not able to moderate the relationship between current 


\section{EPRA International Journal of Research and Development (IJRD)}

ratio and stock returns. This means that the size of the company does not significantly cause the relationship between the current ratio with stock returns to be stronger or weaker as previously thought.

This condition implies that a low CR is usually considered to indicate a problem in liquidity and is an early indicator of the company's inability to meet its short-term obligations. High CR, which means high liquidity also shows that companies are less able to manage money to create money, which in turn can reduce company profitability. Investors often assess that the greater CR shows the company's ability to meet its operational needs, especially working capital, which is very important to maintain the performance of the company's performance, which in turn affects stock price performance. This can provide confidence to investors to own the company's shares so as to increase stock returns.

\section{Company size can moderate the relationship between Debt to Equity Ratio with Stock Return}

The results showed that company size was not able to moderate the relationship between Debt to Equity Ratio with stock returns. This means that the size of the company does not significantly cause the relationship between Debt to Equity Ratio with stock returns to be stronger or weaker as previously thought.

Based on this, it can be explained by the inclusion of company size as a moderating variable that is not able to weaken or strengthen the positive influence of DER on stock returns. The larger the company, the DER effect in increasing returns is weakening. This is due to the greater size of the company, the risk obtained will decrease and the company's ability to generate returns will decrease along with the decrease of the level of risk. The results of this study are not in line with research conducted by Purwitajati \& Putra (2016) which states that company size used as a moderating variable is stated to be able to moderate by weakening the positive influence of DER on stock returns.

\section{Company size can moderate the relationship between Price Earning Ratio and Stock Return}

The results showed that company size was not able to moderate the relationship between price earnings ratio and stock returns. This means that the size of the company does not significantly cause the relationship between the price earnings ratio with stock returns to be stronger or weaker as previously thought.

According to Harahap (2011), a high PER indicates investor expectations about the company's achievements in the future are also high. This ratio is an indicator of how much investors are willing to pay how much per rupiah of reported profits. An increase in corporate profits can be characterized by an increase in share prices, which also has an impact on increasing the PER ratio.

\section{Company size can moderate the relationship between Price to Book Value and Stock Return}

The results showed that company size was not able to moderate the relationship between price to book value and stock returns. This means that the size of the company does not significantly cause the relationship between price to book value and stock returns to be stronger or weaker as previously thought.

According to Brigham and Houston (2010) the ratio of stock prices to the price of his book gives an indication of investors' views of the company. Companies that are considered good by investors can be interpreted as companies with safe profits and cash flow and continue to experience growth. Such companies will be sold at a higher book price ratio, compared to companies that have a low rate of return. The theory shows that the actual PBV ratio is not fully taken into account by investors, in purchasing shares. Because the greater PBV value indicates that the company has safe profits, secure cash flow and is in its infancy. So investors think that the company will be profitable to invest.

\section{CONCLUSION}

Based on the results of the analysis and discussion that has been done, the following conclusions can be drawn: 1) ROA has a positive effect on stock returns; 2) CR does not have a significant positive effect on stock returns; 3) DER has a positive effect on stock returns; 4) PER has a positive effect on stock returns; 5) PBV has no effect on stock returns; and 6) Company size is not able to moderate the relationship between ROA, CR, DER, PER, PBV with stock returns.

\section{Limitation}

This research is inseparable from the shortcomings and limitations. Limitations in this study are as follows: 1) Limited research uses independent variables, namely the variable Return on Assets, Current Ratio, Debt to Equity Ratio, Price Earning Ratio and Price to Book Value; 2) This research is only conducted by Property, Real Estate, and Building Construction companies, not yet able to represent all companies listed on the Indonesia Stock Exchange so that the results of this study will be able 


\title{
SJIF Impact Factor: 7.001| ISI I.F.Value:1.241| Journal DOI: 10.36713/epra2016 \\ ISSN: 2455-7838(Online) \\ EPRA International Journal of Research and Development (IJRD)
}

\author{
Volume: 6 | Issue: 1 | January 2021
}

- Peer Reviewed Journal

to give different results if it is carried out on other types of companies.

\section{Suggestions}

As explained earlier that this study contains limitations. But the results of this study can at least motivate further research. By considering the existing limitations, it is expected that future research will improve the following factors: 1) For companies should be able to increase profitability so that financial performance becomes good in the eyes of investors and can attract investors to invest; 2) In the next research, it is better to add several companies from various sectors that will be studied in order to better describe the condition of each company, researchers also need to add a longer research period so that the results can be generalized and add one or more variables that further affect stock returns ; 3) For investors and company management it is better to optimize return on assets, debt equity ratio, and price earning ratio, because these three variables have a positive and significant relationship to stock returns. In addition, especially for investors and investment managers in the decision to purchase shares in the capital market not only consider the ratio analysis approach in assessing the return of a stock, but also consider factors outside the company policy such as market conditions that occur as well as other external factors due to this will indirectly affect the benefits obtained in making investments.

\section{DAFTAR PUSTAKA}

1. Ang, Robert. 1997. Pasar Modal Indonesia. Edisi Pertama. Media Soft. Jakarta.

2. Antara, S., Sepang, J., \& Saerang, I. S. 2014. Analisis Rasio Likuiditas, Aktivitas, dan Profitabilitas Terhadap Return Saham Perusahaan Wholesale Yang Terdaftar di Bursa Efek Indonesia. Jurnal EMBA, Vol 2, No. 3, hal. 902-911.

3. Arista, Desy dan Astohar. 2012. Analisis FaktorFaktor Yang Mempengaruhi Return Saham (Kasus pada Perusahaan Manufaktur yang Go Public di BEI periode Tahun 2005-2009).Jurnal Ilmu Manajemen dan Akuntansi Terapan, Vol. 3, No. 1

4. Bramantyo Nugroho dan Daljono. 2013. Pengaruh Kinerja Keuangan Terhadap Return Saham (Studi Empiris Perusahaan Automotive and Component yang Listing di Bursa Efek Indonesia Periode 2005-2011). Diponegoro Journal of Accounting Vol. 2, No. 1, hal. 1-11

5. Chrismas Bisara. 2015. Pengaruh Kinerja Keuangan Terhadap Return Saham. Jurnal Ilmu \& Riset Akuntansi. Vol. 4, No. 2

6. Farkhan, \& Ika. 2012. Pengaruh Rasio Keuangan Terhadap Return Saham Perusahaan Manufaktur di Bursa Efek Indonesia (studi kasus pada perusahaan manufaktur sektor food and beverage). Jurnal Value Added. Vol 9, No. 1, Hal. 1-18.

7. Garin Pratiwi Solihati. (2019). Analysis of Factors Affecting Abnormal Return Stock in Private Banking Sector Registered in Indonesia Stock Exchange 2015-2017. International Journal of Academic Research in Accounting, Finance and Management Sciences. Vol. 9, No. 2

8. Gitman, L. J., \& Zutter, C. J. 2012. Principles of Managerial Finanance. England: Pearson Education Limited.

9. Gujarati, D. N. 2012. Dasar-dasar Ekonometrika. Terjemahan Mangunsong, R.C., Salemba Empat, buku 2, Edisi 5, Jakarta

10. Hafidz Ridho Ansori dan Safira. 2018. Analisis Pengaruh Manajemen Risiko Terhadap Profitabilitas (Studi Komparatif Pada Bank Umum Konvensional dan Bank Umum Syariah yang Terdaftar di OJK Periode 2012-2015). Jurnal Profita. Vol. 11. No. 1. April.

11. Husnan, Suad. 2015. Dasar-dasar Teori Portofolio dan Analisis Sekuritas. Edisi 5. BPFE, Yogyakarta.

12. Jogiyanto, H. 2015. Teori Portofolio dan Analisis Investasi. Edisi 9. Yogyakarta: PT BPFE.

13. Mathilda, M. 2012. Pengaruh Price Earnings Ratio Dan Price To Book Value Terhadap Return Saham Indeks LQ 45. Jurnal Akuntansi, Vol. 4, No. 1, hal. 1-21.

14. Nesa Anisa. 2015. Analisis Faktor-Faktor Yang Mempengaruhi Return Saham (Studi Kasus Pada Perusahaan Sub Sektor Automotive And Components Yang Terdaftar Di Bursa Efek Indonesia Periode 2010-2014). Perbanas Review, Vol. 1, No. 1, November

15. Rista Bintara and Putri Renalita Sutra Tanjung. (2019). Analysis of Fundamental Factors on Stock Return. International Journal of Academic Research in Accounting, Finance and Management Sciences. Vol. 9, No. 2

16. Slamet Mudjijah; Zulvia Khalid; dan Diah Ayu Sekar Astuti. (2019). Pengaruh Kinerja Keuangan dan Struktur Modal Terhadap Nilai Perusahaan yang Dimoderasi Variabel Ukuran Perusahaan. Jurnal Akuntansi dan Keuangan. Vol. 8, No. 1 April

17. Teguh Jiwandono. 2014. Analisis Faktor Fundamental Terhadap Harga Saham Sektor Perbankan yang Go Public di Indeks Kompas 100. Jurnal Ilmu Manajemen I, Vol. 2 No. 3 Juli

18. Thrisye, R. Y., \& Simu, N. 2013. Analisis Pengaruh Rasio Keuangan Terhadap Return Saham BUMN Sektor Pertambangan periode 2007-2010. Jurnal Ilmiah Akuntansi dan Bisnis, Vol. 8 No. 2, Hal. 75-81.

19. Vitri Hanivah dan Indra Wijaya. 2018. Pengaruh Debt to Equity Ratio, Total Asset Turnover, Inflasi dan BI Rate terhadap Return Saham. Jurnal Profita. Vol. 11. No. 1. April

20. Vivi Apriliyanti; Hermi; dan Vinola Herawaty. 
2019. Pengaruh Kebijakan Hutang, Kebijakan Dividen, Profitabilitas, Pertumbuhan Penjualan dan Kesempatan Investasi Terhadap Nilai dan Ukuran Perusahaan Sebagai Variabel Moderasi. Jurnal Magister Akuntansi Trisakti. Vol. 6, No. 2

21. Wahyudiono, B. 2014. Mudah Membaca Laporan Keuangan. (Andriansyah, Ed.). Jakarta: Raih Asa Sukses.

22. Widyawati, H. 2012. Pengaruh Ratio Profitabilitas Dan Leverage Terhadap Return Saham (Studi Kasus Pada Industri Automotive dan Alliend Product yang Listed di BEI). Jurnal Dinamika Manajemen, Vol 2, No. 4, Hal. 1-16. 